\title{
Efficacy of velpatasvir and sofosbuvir in treatment of chronic hepatitis $\mathbf{C}$.
}

\footnotetext{
1. FCPS (Medicine)

Professor Medicine

Independent Medical College Faisalabad.

2. FCPS (Medicine)

Senior Registrar Medicine Independent Medical College Faisalabad

3. FCPS (Medicine)

Senior Registrar Medicine

University Medical \& Dental College

Faisalabad.
}

Correspondence Address:

Dr. Hafiz Bilal Bashir

Senior Registrar Medicine

Independent Medical College/Hospital,

Faisalabad.

bilal_bashir@hotmail.com

Article received on:

$11 / 07 / 2020$

Accepted for publication:

$14 / 10 / 2020$

\begin{abstract}
Muhammad Badar Bashir ${ }^{1}$, Hafiz Bilal Bashir ${ }^{2}$, Mahpara Munir ${ }^{3}$
\end{abstract}
\begin{abstract}
Objective: To determine the efficacy of sofosbuvir and velpatasvir in treatment of all genotypes of chronic HCV infection. Study Design: Descriptive Case study Setting: Department of Medicine Independent University Hospital Faisalabad. Period: December 2019 to May 2020. Material \& Methods: Among patients of chronic hepatitis C presenting in the medical OPD of independent university hospital willing to participate, 80 were included in this study. They were given combination of sofosbuvir and velpatasvir 400/100 mg (FDC) once daily. They were monitored by serum ALT and PCR to HCV quantitative after one month and after three months. End point was undectable PCR to HCV Quantitative. We observed the number of patients achieving SVR after taking combination of sofosbuvir and velpatasvir. Results: In our study, out of 80 cases of chronic hepatitis c $40 \%(n=32)$ were male and $60 \%(n=48)$ were females, end result revealed $98.8 \%(n=79)$ achieved SVR and their PCR remained negative at the end of 03 months and $1.3 \%(n=01)$ remained positive despite antiviral therapy for 03 months. Conclusion: We concluded that using fixed dose combination of sofosbuvir and velpatasvir achieve SVR of $98.8 \%$.
\end{abstract}

Key words: $\quad$ Chronic Hepatitis C, Sofosbuvir, Serum ALT, Velpatasvir.

Article Citation: Bashir MB, Bashir HB, Munir M. Efficacy of Velpatasvir and Sofosbuvir in treatment of chronic hepatitis C. Professional Med J 2021; 28(2):153-157. https://doi.org/10.29309/TPMJ/2021.28.02.5535

\section{INTRODUCTION}

Hepatitis $C$ is an infectious disease of liver caused by hepatitis $\mathrm{C}$ virus (HCV). Worldwide 143 million people are infected with (HCV). ${ }^{1}$ Pakistan is endemic country for HCV and about $6.8 \%$ of general population is infected with this virus with $61.3 \%$ of people infected with genotype $3 a^{2}$

HCV spreads via blood to blood contact such as intravenous drug abuse, blood transfusion, tattooing, needle stick injuries and surgical procedures. ${ }^{3}$ Acute infection is rarely symptomatic and usually goes unnoticed. Main symptoms of acute HCV infection, when present are nausea, vomiting, muscle and joint pains, jaundice, dark urine and pale stool. Although acute infection doesn't cause acute liver failure but causes hepatocellular injury and increases liver enzymes. ${ }^{4}$

There is no vaccine for hepatitis C. ${ }^{5}$ About 80 percent of acute infection leads to chronicity with hepatocellular injury and regeneration. This infection if left untreated may cause cirrhosis of liver and even hepatocelluar carcinoma in 30 to $50 \%$ of the patients. ${ }^{6}$

Previously hepatitis $\mathrm{C}$ was treated with injectible interferon and ribaviron based therapy which had less than 50 percent cure rate and greater side effects $^{7}$ then newer drugs which target nonstructural proteins have been developed. ${ }^{8}$ Sofosbuvir was the first oral drug to be developed for the treatment of chronic HCV. ${ }^{9}$ Sofosbuvir and ribavirin with or without pegylated interferon has been used for twelve weeks in the recent past to treat HCV genotypes 2 and $3 .^{10}$

In June 2016 Food and drugs administration (FDA) approved combination of sofosbuvir and valpatasvirfor the treatment of chronic HCV with or without cirrhosis for all genotypes. ${ }^{11}$

Sofosbuvir works by inhibiting viral protein 
NS5B. ${ }^{12}$ Velpatasvir is NS5A inhibitor which is used along with sofosbuvir for the treatment of all genotypes of chronic HCV. ${ }^{13}$

In 2018 European association for the liver disease (EASL) also recommended the combination of sofosbuvir and valpatasvir for the treatment of all genotypes of chronic HCV in patients without cirrhosis or with compensated cirhosis. ${ }^{14}$

With the introduction of fixed dose combination (FDC) highly efficacious oral antiviral sofosbuvir and velpatasvir, it is claimed to achieve SVR of $91 \%$ to $96 \%$ in treatment naïve and experienced patients without cirrhosis with 12 weeks of therapy. ${ }^{15}$ With such convenient and efficacious therapy it is now possible to reduce HCV burden and reduce its transmission to healthy persons ${ }^{16}$ in endemic countries like Pakistan.

My research will focus on finding the efficacy of (Fixed dose combination) FDC of sofosbuvir and velpatasvir in all genotypes in Pakistan. This is needed because all of research on sofosbuvir and velpatasvir has been done in other countries; Pakistan being endemic country for chronic hepatitis $C$ has not been investigated so extensively.

\section{MATERIAL \& METHODS}

This study was conducted in department of Medicine Independent University Hospital Faisalabad, No IUH/IRB/00009. Total duration of study was 06 months from December 2019 to May 2020. Patients were selected by using convenience sampling. Study design was descriptive case study. Sample size was calculated by using sample size calculator.

By using sample size calculator

Margin of Error $=5 \%$

Confidence interval $=95 \%$

Prevalence of $\mathrm{HCV}=5.46 \%$

Sample Size $=80$

\section{Inclusion criteria}

All the patients of chronic hepatitis $\mathrm{C}$ Both genders will be included Age $>20$ years and $<80$ years

\section{Exclusion Criteria}

Patient with decompensated cirrhosis

Patient with documented HCC

After taking approval from hospital ethical review committee, patients fulfilling the selection criteria were enrolled in the study and informed consent was taken from patients/caregivers. Detailed history was recorded in each case. Detailed physical examination with special emphasis on abdomen and relevant was conducted in all patients. Serum ALT levels and PCR to HCV RNA advised on first visit after one month and after 3 months in all patients through hospital pathology laboratory. Collected data was recorded in a structured Performa by me.

All the data was analyzed by using SPSS 22.Mean and standard deviation was calculated for all the quantitative variables like age, serum ALT. Frequency and percentage was calculated for all the qualitative variables like gender.

\section{RESULTS}

In our study, out of 80 cases of chronic hepatitis C $40 \%(n=32)$ were male and $60 \%(n=48)$ were females (Table-I). Age distribution reveals $26.3 \%$ $(n=21)$ of patients belongs to age range of 2435 years, $25 \%(n=20)$ of patients belong to age range of $35-45$ years, $36.3 \%(n=29)$ of patients belong to age range $45-55$ years, $12.5 \%(n=10)$ patients were older than 55 years (Figure-1). Regarding serum ALT 23.8\% $(n=19)$ of patients were having Serum ALT between $25-45 \mathrm{mg} / \mathrm{dl}$, $42.5 \%(n=34)$ of patients were having Serum ALT between $45-65 \mathrm{mg} / \mathrm{dl}, 32.5 \%(n=26)$ of patients were having serum ALT between $65-85 \mathrm{mg} / \mathrm{dl}$ and $1.3 \%(n=01)$ of the patients was having serum ALT > 85mg/dl (Figure-2). Regarding PCR 98.8\% $(n=79)$ were having undetectable viral load after one month (Table-IV) and three months and 1.3\% $(n=01)$ was having detectable viral load after one month and virus remained detectable even after 03 months of antiviral therapy (Table-V).

End result revealed $98.8 \% \quad(n=79)$ get cured and their PCR remained negative at the end of 03 months and 1.3\% $(n=01)$ remained positive despite antiviral therapy for 03 months (Table-VI). 


\begin{tabular}{|c|c|c|c|c|c|}
\hline & $\mathbf{N}$ & Minimum & Maximum & Mean & Std. Deviation \\
\hline Serum_ALT & 80 & 22.00 & 89.00 & 57.3500 & 16.07664 \\
\hline Age & 80 & 27.00 & 65.00 & 43.4125 & 9.74185 \\
\hline
\end{tabular}

Table-I. Descriptive Statistics.

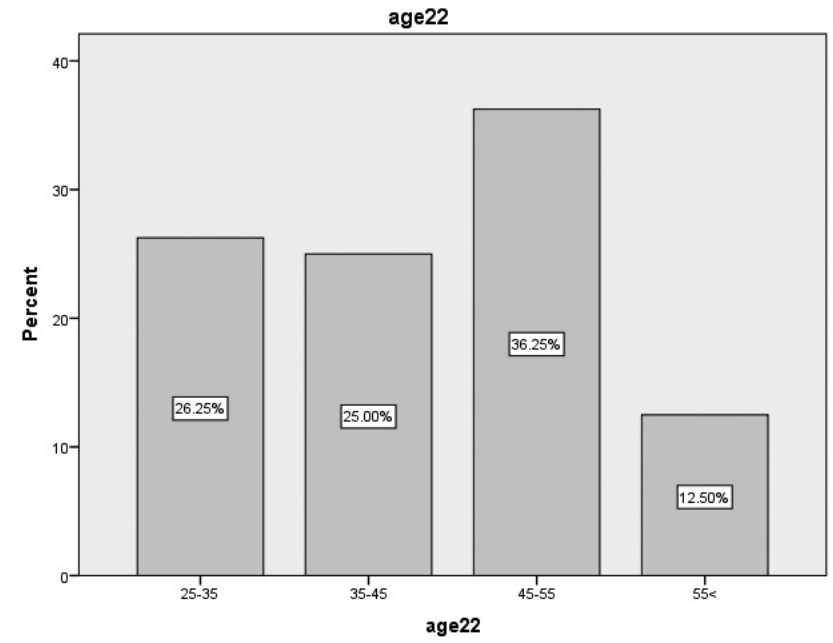

Figure-1

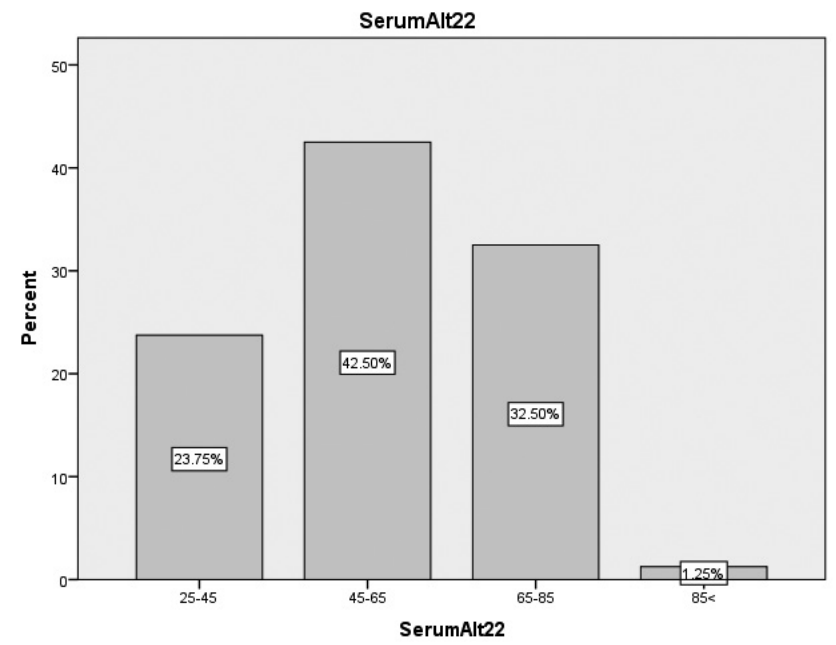

Figure-2

\begin{tabular}{|c|c|c|c|c|c|}
\hline \multicolumn{1}{|c|}{} & Frequency & Percent & Valid Percent & Cumulative Percent \\
\hline \multirow{3}{*}{ Valid } & Positive & 1 & 1.3 & 1.3 & 1.3 \\
\cline { 2 - 6 } & Negative & 79 & 98.8 & 98.8 & 100.0 \\
\cline { 2 - 6 } & Total & 80 & 100.0 & 100.0 & \\
\hline
\end{tabular}

Table-II. PCR after one Month.

\begin{tabular}{|l|c|c|c|c|c|}
\hline \multicolumn{2}{|c|}{} & Frequency & Percent & Valid Percent & Cumulative Percent \\
\hline \multirow{3}{*}{ Valid } & Positive & 1 & 1.3 & 1.3 & 1.3 \\
\cline { 2 - 6 } & Negative & 79 & 98.8 & 98.8 & 100.0 \\
\cline { 2 - 6 } & Total & 80 & 100.0 & 100.0 & \\
\multicolumn{2}{|c|}{ Table-III. PCR after 03 Months. }
\end{tabular}

\begin{tabular}{|c|c|c|c|c|c|}
\hline & & Frequency & Percent & Valid Percent & Cumulative Percent \\
\hline \multirow{3}{*}{ Valid } & Achieved SVR & 79 & 98.8 & 98.8 & 98.8 \\
\hline & Not Achieved SVR & 1 & 1.3 & 1.3 & 100.0 \\
\hline & Total & 80 & 100.0 & 100.0 & \\
\hline
\end{tabular}

\section{DISCUSSION}

With the approval of fixed dose oral antiviral therapy, safe and effective combination regimens are now available for the majority of chronically infected patients with HCV. Cure rates greater than $90 \%$ can be achieved in most patients, regardless of genotype, treatment experience, or the presence of cirrhosis. A fixed dose combination of antiviral drugs which is effective in all genotypes of $\mathrm{HCV}$ will eliminate the need for expensive pretesting and will reduce the cost burden for developing countries. ${ }^{17}$ Although the proportion of patients who do not achieve SVR with currently approved regimens is small, the absolute number of treatment failures will increase as the rate of treatment taken increases. 
Direct acting oral antiviral failures has no medical alternative available at this time. However those patients who failed to achieved SVR on Sofosbuvir and velpatasvir. The addition of voxilaprevir for 12 weeks increases SVR rate to 98\% (POLARIS -1 and POLARIS-4). ${ }^{18}$

In this study, the combination of sofosbuvir and velpatasvir for 12 weeks was shown to be safe and highly effective for treatment naive patients with HCV infection irrespective of genotype. The result of our study is comparable with the studies done abroad (ASTRAL-1) and published in New England journal of medicine. ${ }^{19}$

Currently approved treatment regimens have durations of 12 to 24 weeks, depending on the choice of treatment regimen and the patient's baseline characteristics, such as HCV genotype, treatment history, and presence or absence of cirrhosis.

The efficacy of sofosbuvir and velpatasvir in decompensated cirrhosis is reduced to $83 \%$ (SVR) for twelve week treatment, but with the addition of ribavirin to sofosbuvir and velpatasvir increases the SVR rate from $83 \%$ to $94 \% .{ }^{20}$

The possibility of shortening the duration of treatment has been a research objective, in particular for treatment regimens without ribavirin. Several clinical trials have studied various combinations of direct acting oral antiviral for 4 weeks, but with uniformly disappointing results. ${ }^{21}$ In addition, the high levels of SVR across all genotypes suggest pangenotypic use of sofosbuvir and velpatasvir.

This study was limited by its small sample size. Only 80 treatment naïve patients were included in this study out of which 79 people get cured and 01 patient remained positive despite antiviral. Secondly genotying was not done in our patients because of pangenotyic regime was given to the patients covering all genotypes.

\section{CONCLUSION}

We concluded that fixed dose combination of velpatasvir and sofosbuvir is highly efficacious and having SVR of $98.8 \%$ in treatment native patients without cirrhosis.

Copyright $(14$ Oct, 2020.

\section{REFERENCES}

1. Nicholas J Kassebaum, Megha Arora, Ryan M Barber et al, Global, regional, and national incidence, prevalence, and years lived with disability for $\mathbf{3 1 0}$ diseases and injuries. Lancet. 2016, Oct, 388: 15451602.

2. Umer $\mathbf{M}$, lqbal $\mathrm{M}$. Hepatitis $\mathbf{C}$ virus prevalence and genotype distribution in Pakistan: Comprehensive review of recent data. World J Gastroenterol. 2016 Jan 28;22(4):1684-700. doi: 10.3748/wjg.v22.i4.1684. PMID: 26819533; PMCID: PMC4721999.

3. Moosavy SH, Davoodian P, Nazarnezhad MA, Nejatizaheh A, Eftekhar E, Mahboobi H. Epidemiology, transmission, diagnosis, and outcome of Hepatitis C virus infection. Electron Physician. 2017 Oct 25;9(10):5646-5656. doi: 10.19082/5646. PMID: 29238510; PMCID: PMC5718874.

4. Manka, Paul; Verheyen, Jens; Gerken, Guido; Canbay, Ali. Liver failure due to acute viral hepatitis (A-E)". Visceral Medicine. April 2016, 32: 80-85.

5. Webster DP, Klenerman P, Dusheiko GM. Hepatitis C. Lancet. 2015 Mar 21;385(9973):1124-35. doi: 10.1016/ S0140-6736(14)62401-6. Epub 2015 Feb 14. PMID: 25687730; PMCID: PMC4878852.

6. Lawitz E, Poordad FF, Pang PS, et al.: Sofosbuvir and ledipasvir fixed-dose combination with and without ribavirin in treatment-naive and previously treated patients with genotype 1 hepatitis $C$ virus infection (LONESTAR): an open-label, randomized, phase 2 trial. Lancet. 2014, 383:515-23.

7. Kim A. Hepatitis C Virus. Ann Intern Med. 2016 Sep 6;165(5):ITC33-ITC48. doi: 10.7326/AITC201609060. PMID: 27595226.

8. Khaliq S, Raza SM: Current status of direct acting antiviral agents against hepatitis $\mathbf{C}$ virus infection in Pakistan. Medicina (Kaunas). 2018 Nov 5; 54(5):80.10.3390/medicina54050080.

9. McQuaid T, Savini C, Seyedkazemi S: Sofosbuvir, a significant paradigm change in HCV treatment. J Clin Transl Hepatol. 2015, 3:27-35.10.14218/ JCTH.2014.00041.

10. Zeuzem S, Dusheiko GM, Salupere R, et al.: Sofosbuvir and ribavirin in HCV genotypes 2 and 3. N Engl J Med. 2014, 370:1993-2001.10.1056/NEJMoa1316145 
11. United States Food and Drug Administration. FDA approves Epclusa for treatment of chronic hepatitis C virus infection. (2016). Accessed: December 12, 2019:

12. Sovaldi FDA Label. (2019). Accessed: December 12, 2019: https://www.accessdata.fda.gov/drugsatfda docs/label/2019/212480s000lbl.pdf.

13. Epclusa FDA Label. (2016). Accessed: December 12, 2019: https://www.accessdata.fda.gov/drugsatfda_ docs/label/2016/208341s000lbl.pdf.

14. European Association for the Study of the Liver: EASL recommendations on treatment of hepatitis $\mathbf{C} . \mathrm{J}$ Hepatol. 2018, 69:461-511.10.1016/j.jhep.2018.03.026.

15. Foster GR, Afdhal N, Roberts SK, Bräu N, Gane EJ, Pianko S, Lawitz E, Thompson A, Shiffman ML, Cooper C, Towner WJ, Conway B, Ruane P, Bourlière $M$, Asselah T, Berg T, Zeuzem S, Rosenberg W, Agarwal K, Stedman CA, Mo H, Dvory-Sobol H, Han L, Wang J, McNally J, Osinusi A, Brainard DM, McHutchison JG, Mazzotta F, Tran TT, Gordon SC, Patel K, Reau N, Mangia A, Sulkowski M; ASTRAL-2 Investigators; ASTRAL-3 Investigators. Sofosbuvir and Velpatasvir for HCV Genotype 2 and 3 Infection. N Engl J Med. 2015 Dec 31;373(27):2608-17. doi: 10.1056/NEJMoa1512612. Epub 2015 Nov 17. PMID: 26575258.
16. Wedemeyer H, Dore G, Estimates on HCV disease burden worldwide-filling the gaps. J. Viral Hepat. Jan 2015, 22:1-5.

17. Wendt A, Adhoute X, Castellani P, et al. Chronic hepatitis C: future treatment. Clin Pharmacol 2014; $6: 1-17$.

18. Bourlière M, Gordon SC, Flamm SL, et al. Sofosbuvir, Velpatasvir, and Voxilaprevir for Previously Treated HCV Infection. N Engl J Med. 2017; 376:2134-46.

19. Feld JJ, Jacobson IM, Hézode C, Asselah T, Ruane PJ, Gruener N, Abergel A, Mangia A, Lai CL, Chan HL, Mazzotta F, Moreno C, Yoshida E, Shafran SD, Towner WJ, Tran TT, McNally J, Osinusi A, Svarovskaia E, Zhu Y, Brainard DM, McHutchison JG, Agarwal K, Zeuzem S; ASTRAL-1 Investigators. Sofosbuvir and Velpatasvir for HCV Genotype 1, 2, 4, 5, and 6 Infection. N Engl J Med. 2015 Dec 31;373(27):2599-607. doi: 10.1056/ NEJMoa1512610. Epub 2015 Nov 16. PMID: 26571066.

20. Curry MP, O'Leary JG, Bzowej N, et al. Sofosbuvir and Velpatasvir for HCV in Patients with Decompensated Cirrhosis. N Engl J Med. 2015; 373:2618-28.

21. Zarębska-Michaluk D. Viral hepatitis $\mathbf{C}$ treatment shortening - what is the limit? Clin Exp Hepatol. 2019; 5:265-70.

\begin{tabular}{|c|c|c|c|}
\hline \multicolumn{4}{|c|}{ AUTHORSHIP AND CONTRIBUTION DECLARATION } \\
\hline Sr. \# & Author(s) Full Name & Contribution to the paper & Author(s) Signature \\
\hline 1 & M. Badar Bashir & Idea, Guidance. & $1.8 x$ \\
\hline 2 & Hafiz Bilal Bashir & Data collection, Write up. & \\
\hline 3 & Mahpara Munir & Proof reading. & matis. \\
\hline
\end{tabular}

